Global Conferences Series:

Social Sciences, Education and Humanities (GCSSSEH), Volume 2, 2019

The $2^{\text {nd }}$ International Conference on Sustainable Development \& Multi-Ethnic Society

DOI: https://doi.org/10.32698/GCS.0172

\title{
Project-Based Learning: Improving Historical Thinking Skills Ability
}

\author{
Muhammad Zaim Najmi Mohd Rahim ${ }^{1}$, Abdul Razaq Ahmad ${ }^{2}$, Mohd Mahzan \\ Awang $^{3}$, Shakila Che Dahalan ${ }^{4}$ \\ ${ }^{1}$ SK Sungai Passai, Sibu, Sarawak, Malaysia \\ ${ }^{234}$ Faculty of Education UKM, MALAYSIA \\ E-mail: zumiela7@gmail.com
}

\begin{abstract}
In line with the 21st Century Learning age, Project-Based Learning is a form of pedagogy capable of inculcating creativity and critical thinking skills among primary school pupils. Project-Based Learning is rarely carried out for teaching History. The use of Project-Based Learning in History could potentially improve pupils' Historical Thinking Skills ability. Historical Thinking Skills is essential to help develop the pupils' cognitive and empathy values toward a certain topic in their History lessons. This concept paper will discuss the use of Project-Based Learning method to improve Historical Thinking Skills on the primary school level. This discussion will focus on the advantages, issues and challenges to use Project-Based Learning in the History subject. Additionally, this concept paper will also discuss previous researches related to the implementation of Project-Based Learning in teaching History. This discussion will hopefully be able to provide an alternative pedagogy for History teachers to improve the Historical Thinking Skills ability and expand the knowledge and values among the pupils.
\end{abstract}

Keywords: Project-Based Learning, historical thinking skills, history education

\section{Introduction}

The start of the new technological age wave known as The Fourth Industrial Revolution and the era of Digital Economy has brought about new challenges to the global market in terms of skilled workforce who are not only equipped with deep knowledge in their respective fields, but they should also be armed with an array of necessary soft skills. This trend drives the preparation of the future generation to be equipped with various knowledge and skills.
This development is also one of the reasons the Malaysia Ministry of Education went forward with their aim to implement pupils-centered teaching strategies with a focus on high order thinking skills in all of their curriculums including primary and secondary schools by introducing the Malaysia Education Blueprint 2013 - 2025. This step was taken to unite the communication, spiritual, attitude and value, humanity, self-esteem, physical development and esthetics and science and technology with a critical, creative and innovative thinking in all subjects (Bahagian Pembangunan Kurikulum, 2014). 
In line with the current technological development era and the development of the 21st Century Learning, the History subject in school has a role to sustain creativity and promote critical thinking among pupils without disregarding the promotion of patriotism values as the main focus. History itself is an agent of unity and nation building to form a society with a love for their country and an absolute patriotism spirit (Rohaimi \& Ramlah, 2015). History is not limited as a subject concerned with only understanding past events chronologically, but it can be a subject capable of promoting pupils thinking skills in evaluating and reflecting on certain past events by using Historical Thinking Skills.

Inadequate mastery of Historical Thinking Skills causes pupils to find it hard to master a certain topic and contents of the History subject. Additionally, ineffective techniques and teaching strategies by History teachers cause pupils to further become disinterested in the subject. History is frequently regarded as a boring subject because of the teachers' pattern and teaching practices which are more focused as a one-way explanation without involving the pupils' critical thinking process even though the contents of the curriculum is capable of inducing a critical thinking process (Mohamad Ikhwan and Anuar Ahmad, 2018). This becomes a challenge for the teachers to understand and determine effective teaching strategies to form a positive perception among the pupils regarding the History subject.

Therefore, History teachers should be skillful in adapting various teaching strategies in order to reinforce pupils' knowledge and skills. The implementation of the Project-Based Learning method, which is one of the learnercentered strategies, is extremely suitable for History Education. However, this strategy is seldomly implemented in the context of History Education especially in primary schools. Project-Based Learning is also more usually applied in the teaching and learning of Science, Technology, Engineering and Mathematics (STEM).

\section{Historical Thinking Skills}

Historical Thinking Skills is an important skill in the teaching and learning process of History. This skill is a cognitive process which helps pupils understand how historians connect past events based on history evidences to determine the significance of an event in order to boost critical and creative thinking (Bahagian Pembangunan Kurikulum, 2014). In Malaysia, the historical thinking skill model includes five elements i.e. Understanding Chronology, Exploring Evidences, Making Interpretations, Fabricate Imaginations and Form Rationalisations (Bahagian Pembangunan Kurikulum, 2014).
Puteh et al (2010) defined Historical Thinking Skills as a process of using historical information, making interpretations regarding contexts, perspectives and able to see historical facts to understand the past. The learning of History by using Historical Thinking Skills is able to increase a higher order thinking skill (Sarmila \& Abdul Razak, 2017). This proves that the application of Historical Thinking Skills in History subject will help pupils to understand the contents of the topic and subsequently make evaluations for every chronological event that happened.

History Thinking Skills is important for primary school pupils because the mastery of History Thinking Skills will help give a strong base for them to understand the History subject in their secondary school later on which will cover a wider and deeper scope of History. Their inability to master History Thinking Skills will cause them to fall behind in mastering their topics. This is because there is a correlation between History Thinking Skills mastery and achievement in the History subject. It was proven in a study by M. Kaviza (2019) who stated that all the History Thinking Skills constructs are a contributing factor in achieving better results in the History subject.

\section{Project-Based Learning Concept}

The Project-Based Learning approach is a constructivism learning process driven by the Constructivism Theory by John Dewey (Burcu Gulay, 2014). Through the constructivism approach, pupils will play an active role throughout the learning process by getting involved in the discussion, debating ideas, and sharing opinions rather than reading and listening passively. Through this approach, individual interactions play a vital role. Pupils will not only receive information but will search and form information based on the projects executed (Perkins, 1999).

John W. Thomas (2000) proposed five characteristics of Project-Based Learning which are curriculum based, pupils-centred, constructive investigation, autonomy and realistic. This learning method which emphasised on the pupils' process of understanding a certain learning concept enables the pupils' thinking skills to develop throughout the learning process. In the context of learning History, pupils will be exposed to a variant of historical events which will allow them to analyse and evaluate said events.

According to Katz and Chard in Romarzila, Zanaton and Sharifah Nor Puteh (2018), defining Project-Based Learning as an in-depth investigation process regarding a topic related to a real-world situation is capable in motivating pupils to explore more and learn. The teaching of various topics in History will be connected more closely to pupils' 
lives through assorted applied project activities. The main focus of Project-Based Learning is not only to look for an answer to a question but also to look for more information in connection with the topics being learned.

According to Nitche Isa Medina and Mai Shihah (2013), Project-Based Learning can be defined as a pedagogy method which has meaningful questions and close to the pupils' real world, must have a product or an artifact produced by the pupils at the end of the project, integrates elements of information and communication technology as well as can be carried out individually or in a group. Implementation of Project-Based Learning in History which incorporates technology will help give a clearer picture about past events that they have learned and will interests pupils towards History itself.

\section{Advantages of Project-Based Learning}

Project-Based Learning is a good pedagogical method to be included in the national curriculum because the characteristics of the method are pupils centred, increase pupils' involvement in the process of understanding a certain topic and improve pupils' achievement in their learning. A study by Cornelius \& Zolkepeli (2017) found out that the Project-Based Learning method was effective in improving pupils' achievement in learning Science. Meanwhile, a study by Sunyoung Han et al. 2016 shows that a teaching process which integrates Project-Based Learning was effective in improving pupils' achievement in Mathematics' topics such as algebra and geometry.

Project-Based Learning is an active learning situation and is suitable to engage creative and critical thinking among pupils. An active learning process in learning History such as projects, experiments and use of resources will spark interests, liven the learning environment as well as help the pupils to observe and appreciate the learning of History in the classroom (Abdul Razaq Ahmad, Ahamad Rahim and Ahmad Ali Seman, 2013). Monica and Zamri (2019) suggested that Project-Based Learning activity such as scrapbook making is a learner-centred learning process.

Project-Based Learning will also inadvertently encourage pupils to increase their reading habit regarding the topics they are learning. This is supported by Bell (2010) who stated that in the process of searching for information for their projects, pupils will double their effort to read more materials related to their topics in order to complete their project perfectly.

Additionally, the development of pupils' social skills can be done through this Project-Based Learning method. The social skills are formed through Project-Based Learning by way of making the pupils work in groups to finish a certain project, learning how to manage activities, synthesising information and trying to finish the project in the time frame given (Kaldi et al., 2011). Project-Based Learning is also able to help pupils learn a multitude of social skills and prepare pupils to collaborate with their friends, work in groups, prepare presentations, communicate, analyse and give reasons [(Siti Fatimah et al., 2006) and Nitche Isa Medina \& Mai Shihah (2017)].

Project-Based Learning can help develop multiple skills and values for the pupils such as communication skill, interpersonal and intrapersonal. A study by Aiedah Abdul Khalek (2012) shows that as an effect from project-based learning, pupils become more involved in their learning process especially in their responsibility, ability to work in a group, strategic learning and their motivation.

Project-Based Learning is more focused in what is gained and learned by the pupils throughout the learning process and not only focusing on the output of the learning process. In the context of History Education, Project-Based Learning is very effective to prompt pupils' thinking skills. Historical Thinking Skills are not something natural but it has to be nurtured through activities such as collecting, reading and analysing multiple historical evidences (Wineburg, 2001). Therefore, an active learning strategy like Project-Based Learning is suitable to be applied by teachers in the teaching and learning process of History Education

\section{Issues and Challenges}

Teachers are supposed to be skilled and have fully mastered the application of Project-Based Learning pedagogy. The current teaching methods in schools are not encouraging pupils to develop their historical thinking skills. Ahmad Rafaai, Abdul Razak and Ahmad Ali (2013) stated that the standard and quality of History teaching are still at a mediocre level because of the teachers' pattern and approach are still the same which means that they are still very tied to the routine of using textbooks, finishing the syllabus and examinations oriented. These attitude and traditional methods used by teachers in schools are hampering pupils' effort towards mastering Historical Thinking Skills. Ahmad Zulhusni \& Mohd Mahzan (2018) are of the opinion that History teachers should have the complete understanding and knowledge regarding the Historical Thinking Skills to be applied in their teaching process.

Time is also a challenge in the application of this Project-Based Learning method. This pedagogical method focuses more on the learning process. Therefore, its application requires more time compared to other teaching 
methods. The small amount of time provided for History subject in primary schools causes the teachers to rush to finish their syllabus. Inadvertently, the pupils were not able to completely dive into the subject and gain the full benefit from the learning process.

The pupils also have limited access to knowledge resources. Project-Based Learning requires the pupils to search for materials from multiple sources. Inadequate access to materials such as limited online access causes the ProjectBased Learning to be ineffective. Schools in rural areas especially in Sabah and Sarawak are still not equipped with infrastructures and facilities such as computers and adequate internet access. Schools outside town areas are also facing unstable internet access connection. All of these are causing the pupils' materials sources to be limited exclusively to their textbooks and therefore unable to help them escape their box-thinking which are becoming their default thinking scope.

\section{Suggestions for Improvement}

In order to ensure Project-Based Learning is implemented correctly, primary school History teachers should be given regular training and professionalism courses to help improve their existing knowledge and skills. Professional development and improving the skills of the History teachers are important to ensure that these skilled teachers can vary their teaching resources so that they can interest their pupils to learn (Mohd Samsudin \& Shahizan Shaharudin, 2012).

The allotted time for History Education in primary schools should be increased gradually. Currently, in primary schools, the allotted time for History is 60 minutes per week or two periods. The increase in time given will enable teachers to apply various active teaching methods such as Project-Based Learning more easily.

The subject of History Education in primary schools should start to receive a proper notice by supposed parties. Compared to other core subjects which are focused on in major examinations such as the UPSR, History Education is still regarded as an elective subject whose main purpose is to complete the core subjects. This focus and pressure on History Education will help give rise to more innovation and attention to the subject History Education itself especially on the primary school level.

ICT physical infrastructure such as computers and the internet access should be improved especially in rural and out-of-town areas. The improvement will help the teachers and pupils to search for more materials online and will bring them closer to the outside world.

\section{Conclusion}

Teaching practices are strongly associated with student Project-Based Learning is capable of helping pupils to master the 21 st century skills by developing the pupils' capacity in terms of their critical thinking, communication, collaboration and creativity. Project-Based Learning integrates all of these aspects through the activities that the pupils have to carry out. Project-Based Learning as a learning strategy concept is immensely suitable to be implemented in the context of History Education to help develop the Historical Thinking Skills and to aid the topics mastery process. In order to realise this particularly honorable effort, teachers have to be more proactive in equipping themselves with a multitude of skills such as becoming more technologically savvy and be brave and open for changes in the education system by moving on from traditional teaching methods and to the $21 \mathrm{st}$ century teaching and learning strategies (Muhammad Alif Shahdan \& Anuar Ahmad, 2018). The role of History teachers as a professional teaching body is indispensable in preparing an enjoyable learning experience, close to the daily lives as well as able to initiate a variety of thinking skills among the pupils. A learning strategy that can bring the pupils closer to their daily lives will be able to ease the pupils' comprehension process towards the History content being learned.

\section{References}

[1] Abdul Razaq Ahmad, Ahamad Rahim \& Ahmad Ali Seman (2013). Hubungan Gaya Pembelajaran Aktif Ke Arah Meningkatkan Penghayatan Pembelajaran Sejarah. Himpunan Penyelidikan Pendidikan Serantau 2013, 271 - 283.

[2] Ahmad Rafaai Ayudin, Abdul Razaq Ahmad \& Ahmad Ali Seman (2013). Sumbangan Kualiti Instruksional Dalam Membentuk Orientasi Belajar Sejarah di Malaysia. Himpunan Penyelidikan Pendidikan Serantau 2013, 259 - 270.

[3] Ahmad Zulhusni Mansor, Mohd Mahzan Awang. (2018). Penggunaan Kemahiran Pemikiran Sejarah (KPS) Dalam Kalangan Guru Sejarah di Sekolah Menengah. Seminar Kebangsaan Pascasiswazah Sains Sosial dan Kemanusiaan (SPSSK 2018).

[4] Aiedah Abdul Khalek. (2012). Exploring the Use of Project-Based Learning on Student Engagement at Taylor's University, Malaysia. Jurnal Pendidikan Bitara UPSI. Volume 5, Pages 1-9.

[5] Bahagian Pembangunan Kurikulum. (2014). Dokumen Standard Sekolah Rendah Sejarah Tahun 6. Kementerian Pendidikan Malaysia.

[6] Bell, S. (2010). Project Based Learning for the 21st Century: Skills for the Future. The Clearing House: 
Journal of Educational Strategies, Issues and Ideas, 83(2), 39-43.

[7] Burcu Gulay Tasci. (2014). Project Based Learning from Elementary School to College, Tool: Architecture. Procedia - Sosial and Behavioral Sciences 186 (2015) 770 - 775.

[8] Cornelius Robert Assan \& Zolkepeli Harun. (2017). Kesan Kaedah "Project Based Learning" Terhadap Pencapaian Murid Dalam Amalan Pembelajaran Sains. Seminar Kebangsaan Sains dan Psikologi dalam Pendidikan 2017, 49-58.

[9] Kaldi, S. Filippatou, D., \& Govaris, C. (2011). Project-Based Learning in Primary Schools: Effects on Pupils' Learning and Studies. Education, 39(1), 35-47.

[10] Kaviza, M. (2019). Hubungan Penerapan Elemen Kemahiran Pemikiran Sejarah Dalam Proses Pengajaran Dan Pembelajaran Terhadap Pencapaian Mata Pelajaran Sejarah Dalam Kalangan Murid. JuKu: Jurnal Kurikulum \& Pengajaran Asia Pasifik, 7(1), 30-38.

[11] Mohamad Ikhwan Izam \& Anuar Ahmad. (2018). Kemahiran Pemikiran Sejarah (KPS) dalam Pengajaran dan Pembelajaran Mata Pelajaran Sejarah. Proceedings International Conference on Social Studies (ICOSH 2018).

[12] Mohd Samsudin \& Shahizan Shaharuddin. (2012). Pendidikan dan Pengajaran Mata Pelajaran Sejarah di Sekolah di Malaysia. Malaysian Journal of History, Politics \& Strategy, Vol 39 (2) (December 2012):116-141.

[13] Monica Laina Tonge \& Zamri Mahamod. (2019). Penggunaan Aktiviti Pembelajaran Berasaskan Projek Untuk Meningkatkan Pencapaian Murid Dalam Kemahiran Menulis Karangan. National Conference on Best Teaching Practice \& Innovation 2019.

[14] Muhamad Alif Shahdan \& Anuar Ahmad. (2018). Penggunaan Multimedia dalam Pengajaran dan Pembelajaran Mata Pelajaran Sejarah. Seminar Kebangsaan Pascasiswazah Sains Sosial dan Kemanusiaan (SPSSK 2018):247-255.

[15] Nitce Isa Medina Machmudi Isa \& Mai Shihah Hj Abdullah. (2013). Project Based Learning: Definition, Theory and A Comparison with Problem Based Learning. Cream - Current Research in Malaysia Vol.2, No. 1, January 2013: 181-194.

[16] Nitche Isa Medima Machmudi Isa \& Mai Shihah Abdullah. (2017). Implementasi Pendidikan Berasaskan Hasil melalui Pembelajaran Berasaskan Projek untuk menilai Pencapaian Domain Kognitif Berdasarkan Topik Ekosistem Terancam. Penerbit UTM Press.
[17]Perkins, D. (1999). The many faces of constructivism. Educational Leadership 57 (3), (pp 6-11).

[18] Puteh, S. N., Maarof, N., \& Tak, E. (2010). Students' perception of the teaching of historical thinking skills. In Pertanika Journal of Social Science and Humanities.

[19] Rohaimi Ishak \& Ramlah Jantan. (2015). Tinjauan Persepsi Pelajar Terhadap Mata Pelajaran Sejarah Sekolah Rendah. Asian Education Action Research Journal (AEARJ) ISSN 2289-3180/ Vol 4/ 2015

[20] Romarzila Omar, Zanaton H. Ikhsan \& Sharifah Nor Puteh. (2018). A Comprehensive 21st Century Child Development through Project Based Learning. Journal of Adv Research in Dynamical \& Control Systems, Vol. 10, 06-Special Issue, 2018, pp-1636-1642.

[21] Sarmila Tamoh Deram \& Abdul Razaq Ahmad. (2017). Penggunaan Modul 5E Dalam Meningkatkan Kemahiran Pemikiran Sejarah. International Conference on Education And Regional Development 2017 (ICERD 2017).

[22] Siti Fatimah Mohd Yassin, Baharuddin Aris \& Abdul Hafidz Omar. (2006). Strategi Pembelajaran Projek Pembangunan Produk Multimedia Kreatif Secara Kolaboratif. Jurnal Pendidikan Universiti Teknologi Malaysia, 11, 24-35.

[23] Sunyoung Han et al. (2016). The Effet of Science, Technology, Engineering and Mathematics (STEM) Project Based Learning (PBL) on Students' Achievement in Four Mathematics Topics. Journal of Turkish Science Education. July 2016, 13, 3-29.

[24] Thomas, W. J. (2000). A Review of Research on Project-Based Learning. California: The Autodesk Foundation. Retrieved November 19, 2008, from http:/www.autodesk.com/foundation

[25] Wineburg, S. (2001). Making Historical Sense. In Stearns, P.N. Seixas, P. and Wineburg, S. (eds.). Knowing Teaching and Learning History: National and International Perspectives. New York: New York University Press 